\title{
GRANULAR CELL TUMOUR OF THE LARYNX - A CASE REPORT
}

\author{
P. APPIAH-THOMPSON ${ }^{1}$ and K.K. BAIDOO ${ }^{2}$ \\ ${ }^{1}$ Cape Coast Teaching Hospital, Ear, Nose and Throat, Cape Coast, Ghana, ${ }^{2}$ Korle-Bu Teaching Hospital, \\ Department of Surgery, ENT Unit, P.O. Box 77, Korle Bu, Accra, Ghana
}

DOI: http://dx.doi.org/10.4314/gmj.v49i4.9

Corresponding Author: Dr. Peter Appiah-Thompson

Conflict of Interest: None declared

\section{SUMMARY}

Granular cell tumours (GCTs) are benign tumours rarely found in the larynx even though they are common in the head and neck region. The laryngeal tumour may be asymptomatic but typically patients present with hoarseness of voice, stridor, haemoptysis and dysphagia. The lesion can mimic squamous cell thus deep biopsy must be taken with adjacent normal tissue to confirm this pathology. Immunohistochemical staining is also used. Complete surgical resection of this tumour is the treatment of choice. We present a 25 year old woman with a laryngeal granular cell tumour involving the right vocal cord diagnosed after direct laryngoscopy and biopsy. She was treated by right cordectomy via a laryngofissure approach. We present the case due to the rarity of the laryngeal granular cell tumour and the need to highlight the importance of taking deep biopsies. If biopsies are superficial, an inexperienced pathologist would mistake it for well differentiated carcinoma.

Keywords: Granular cell tumour, larynx, cordectomy, laryngofissure

\section{INTRODUCTION}

Granular cell tumor is one whose histology had been a matter of controversy until they were found to be of neuroectodermal origin as demonstrated by immunophenotypic and ultrastructural evidence. ${ }^{1}$ These tumours occur commonly in the tongue though they can occur in any part of the body. Granular cell tumours (GCTs) may be benign or malignant though the latter versions are rare (2\% of all such tumours). Laryngeal granular cell tumours are rare constituting about $3 \%$ to $10 \%$ of all cases. ${ }^{2}$ We present a case of a granular cell tumor in the larynx and a literature review.

\section{CASE REPORT}

This is a 25 year old woman who presented at the Ear, Nose and Throat Clinic of the Cape Coast Teaching Hospital with progressive unremitting hoarseness of

\author{
Email: appiatee1@gmail.com
}

voice of a year's duration. The patient had been apparently well until the onset of the hoarseness of voice, which had been, treated on several occasions at various health facilities with no improvement. She thus reported to our clinic.

She had been having occasional expectoration of blood-stained sputum and episodes of easy fatigability. She had no associated weight loss, dysphagia, odynophagia or dyspnoea. She occasionally took alcohol and had not been smoking.

On examination, she was a well looking young woman. She was afebrile, anicteric and not pale or dehydrated. Her chest was clinically clear. Her pulse was 90 beats per minute, regular and of good volume. She was conscious and normal. Ears and nose were normal. Oropharyngeal examination was also normal.

Indirect laryngoscopy showed a pale, lobulated mass on the right vocal cord. Both vocal cords moved in abduction and adduction. No neck nodes were palpated. A provisional diagnosis of a right vocal cord tumour was made and patient worked up for direct laryngoscopy. Finding at direct laryngoscopy was an exophytic mass on the posterior half of the right vocal cord as seen in Figure 1.

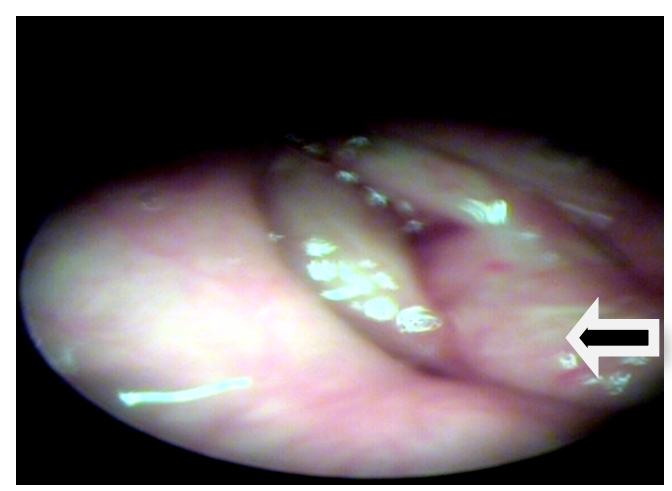

Figure 1 Direct Laryngoscopic View of the Right Vocal Cord Tumour (arrowed) 
ncision biopsy was taken and sent for histopathology. Histopathology report was as follows: "Sections show a tumour lined in areas by squamous epithelium. The tumour showed plump fibroblast-like cells with granular cytoplasm alternating with areas of homogenous eosinophilic stroma. No evidence of malignancy seen. Diagnosis: Granular Cell Tumour"

Patient subsequently had elective tracheostomy followed by laryngofissure and right cordectomy.

Patient had nasogastric tube feeding for 5 days and was decannulated after 7 days. She subsequently recovered well with normal feeding but had an initial weak voice. At six months follow-up, flexible nasolaryngoscopy was done and no evidence of tumour recurrence was found. She has also started speech therapy to improve her voice, which is still hoarse.

\section{DISCUSSION}

GCTs were initially thought to be degenerative diseases of mature striated cells thus called myoblastoma by Abrikossoff in 1926. ${ }^{1}$ Later S100 immuno-histochemical staining of their cytoplasmic granules showed they were true tumours of neural origin, most likely from Schwann cells.

The origin of these tumours being from schwann cells is also supported by findings on electron microscopy which reveals basement membrane resembling perineurium with surrounding angulated bodies. ${ }^{3}$ The tumour largely arises from the substance of the vocal cord though other locations like the arytenoids, false vocal folds, subglottis and postcricoid region have also been reported. ${ }^{4-6}$

Granular cell tumours histologically are characterized by the following features: single or loose clusters of large rounded, polygonal or elongated cells with dirty, granular cytoplasm as was found in this case. The cells also have indistinct borders with small centrally located nuclei and prominent nucleoli. ${ }^{7}$

Other names given to these tumours are granular cell neuroma or schwannoma or myoblastoma, myoblastic tumour, embryonal rhabdomyoblastoma and congenital epulis. ${ }^{8}$

The differential diagnoses of these tumours are rhabdomyoma, rhabdomyosarcoma, and alveolar soft part sarcoma. Whilst granular cell tumours are strongly S-100 positive, rhabdomyoma and rhabdomyosarcoma are negative. Also whilst rhabdomyosarcoma and alveolar soft part sarcoma show marked nuclear pleomorphism, granular cell tumours have relatively uniform nuclei with small nucleoli.

The granular cell tumours also have strongly periodic acid-Schiff (PAS) - positive diastase-resistant cytoplasmic granules. ${ }^{9}$ In children laryngeal papillomatosis is the most common differential diagnosis considered. ${ }^{10}$ The cause is unknown. These tumours have been reported in all ages though extremely rare in children. ${ }^{1,4}$ Our patient was 25 years old.

GCTs present with hoarseness of voice, dysphagia, haemoptysis and otalgia. ${ }^{11}$ Our case only had hoarseness of voice with occasional expectoration of blood-stained sputum. Since these tumours are slow growing, patients may only notice the change in voice or dysphagia after about 6 months before reporting to a health facility. ${ }^{8}$ Our patient noticed she had a change in voice but waited a year before reporting to our hospital.

This was when the dysphonia was progressively worsening. On examination, laryngeal GCTs appear as rounded firm, submucous tumours covered by normal mucosa. They may be polypoid, cystic or sessile and mostly located on the posterior two-thirds of the vocal cord and arytenoid region. They thus resemble polyps or granulomata. They however can be differentiated from polyps which are soft and glistening compared to GCTs which are fibrotic. Granulomata also mostly result from trauma but macroscopically they are similar to the GCTs in that they are located on the posterior larynx. ${ }^{3,12}$

If deep biopsies are not taken, because of squamous proliferation on the surface of the lesion and because they show local invasion of adjacent tissue they can easily be mistaken for well-differentiated carcinoma by an inexperienced pathologist. ${ }^{4,13}$ This may thus be mismanaged by radical surgery such as total laryngectomy. Biopsies must also include normal tissue adjacent to the tumour. ${ }^{3}$ Our patient's histology was reported to show a tumour lined in areas by squamous epithelium.

Malignant GCT is suspected when the tumour is rapidly growing and $\geq 4 \mathrm{~cm}$ in size. Other features of malignancy are nuclear pleomorphism, increased nucleus/cytoplasm ratio, frequent mitosis, cells which are spindle-shaped with necrosis and vacuolated nucleoli. ${ }^{3}$ 
The GCT is managed according to the site and extent of the lesion.

Small tumours are managed by endoscopic resection or by thyrotomy with total resection of the tumour.

Laryngofissure and partial laryngectomy are used for larger tumours. ${ }^{1,14}$ Laryngofissure with cordectomy in the presented case was enough for the complete excision of the tumour. Chemotherapy and radiotherapy have not been used to treat these tumours due to fear of inducing malignant transformation. ${ }^{3}$

Recurrence is uncommon. This has been reported in 2$8 \%$ of cases though now it is suggested the cases reported as recurrences might have been new primary tumours as multiple lesions have been reported to occur in various body parts in some patients. ${ }^{6,15}$ Recurrence may also suggest malignancy. Regular follow-up for at least 3 years with flexible nasolaryngoscopy is key to detecting recurrence early. ${ }^{3,16}$

\section{CONCLUSIONS}

Laryngeal GCT is rare thus a high index of suspicion is needed to diagnose it. Deep biopsies of the tumour with adjacent normal tissue are necessary for accurate diagnosis. An experienced pathologist must report the histology as these tumours can easily be misdiagnosed as carcinoma. Total resection of the tumour must be done either endoscopically or via laryngofissure or thyrotomy to avoid recurrence. Regular follow-up of these patients is necessary to pick up recurrence early.

\section{CONSENT}

Written informed consent was obtained from the patient for publication of this case report and any accompanying images.

\section{ACKNOWLEDGEMENT}

We wish to thank the nurses who helped with the care of this patient most especially the specialist ENT nurses. We also thank this patient for allowing us to write about her case.

\section{REFERENCES}

1. Hwang I, Hwang JE, Choi SH, Nam SY, Cho KJ. Granular Cell Tumors of the Larynx - Report of Three Cases. Korean J Pathol. 2007; 41: 284 - 7
2. Park JH et al. Granular Cell Tumor on Larynx. Clin Exp Otorhinolaryngol. 2010 March; 3(1): 5255.

3. Kamath MP, Shenoy SV, Lobo FD, Majeed NA. Granular Cell Tumour - A Rare Laryngeal Tumor. Iran J Otorhinolaryngol. Vol 26(4),Serial No. 77, Oct 2014

4. Watkinson JC, Gaze MN, Wilson JA. Stell and Maran's Head and Neck Surgery. Oxford, England: Butterworth - Heinemann; 2000. $4^{\text {th }}$ ed. p 236.

5. Dhingra PL, Dhingra S. Diseases of the Ear, Nose and Throat. Elsevier India; 2007.4 ${ }^{\text {th }}$ ed. p 209.

6. Holland RS, Abaza N, Balsara GT, Lesser R. Granular cell tumour of the larynx in a six year old child: case report and review of literature. Ear Nose Throat J. 1998; 77: 652-4,656,658

7. Cheng L, Bostwick DG. Essentials of Anatomic Pathology. Springer, New York; 2006. $2^{\text {nd }}$ ed. $p$ 318

8. Garin L, Barona R, Basterra J et al. Granular cell tumor (Abrikossoff's tumor): a review and our experience. An Otorrinolaringol Ibero Am. 1992; 19(3): 249 - 64

9. Atkinson BE. Atlas of Diagnostic Cytopathology. Saunders Co; 2003. $2^{\text {nd }}$ ed. p 637

10. Dauda AM, Iseh FK. Pediatric laryngeal cell tumour. Afr. J Paediatr Surg. 2000 Jul - Dec;6(2): 124 - 5. doi: 10.4103/0189-6725.54782

11. Victoria LV, Hoffman HT, Robinson RA. Granular Cell Tumour of the Larynx. Laryngol Otol. 1998 Apr; 112(4):373-6.

12. Aydin S, Sanh A, Celebi $O$ et al. Laryngeal granular cell tumour, rare location: A case report. Acta Medica. 2011; 54(1): $41-44$

13. Bailey BJ, Johnson JT. Head and Neck Surgery Otolaryngology. Philadelphia, New York: Lippincott - Raven; 1998. $4^{\text {th }}$ ed. Vol 2. p 1557

14. Arevalo C, Maly B, Eliashar R. Laryngeal granular cell tumour. J Voice. 2008; 22: 339 - 42

15. Batsakis J. Tumors of the Head and Neck. $2^{\text {nd }}$ ed. Baltimore: Williams and Wilkins; 1997: 327 - 31

16. Kim GR, Kim SK, Kim YM. A granular cell myoblastoma of the larynx: A case report. Yonsei Med J. 1965:6 